\title{
Research on the Novel Information and Communication Technology Talent Training Mode under the One Belt and One Road Methodology
}

\author{
Wen-zhun HUANG ${ }^{1, a}$, Lin-tao $\mathrm{YU}^{1, \mathrm{~b}}$ and Shan-wen ZHANG ${ }^{1, \mathrm{c}}$ \\ ${ }^{1}$ Department of Electronic Information Engineering, Xijing University, Xi'an 710123, China \\ ahuangwenzhun@xijing.edu.cn, 'Ivlintao@xaut.edu.cn, cwjdw716@163.com
}

Keywords: Information and Communication; Talent Training; Novel Mode; Guidance and Suggestions; One Belt and One Road Methodology; Performance Optimization.

\begin{abstract}
Talent cultivation of universities should be based on regional economic development needs, show the features of the application. Comprehensive high quality talent training communication engineering professional practice teaching reform in colleges and universities cannot copy other university curriculum system, and should be in the long-term teaching practice to explore and reform unceasingly, in combination with local colleges and universities "comprehensive characteristic" design a kind of ideal practice teaching mode. Heavy theory, therefore, must change light practice, theoretical knowledge in the class of heavy light professional skills training and verification experiment light the idea of comprehensive designing experiments, and improve the recognition of the importance of practice teaching, deepening the reform of practice teaching. We must follow the pace of professional development, and the social demand for talents, stick to the comprehensive investigation, careful argument, the principle of overall planning, step by step implementation, choose their own conditions of best practice teaching mode suitable for school. Only in accordance with the need of society, following the development of modern electronic technology, cultivate the students is one of the most popular social talents. Our methodology combines the advances of the state-of-the-art idea with the traditional education mode which will be meaningful and effective.
\end{abstract}

\section{Introduction}

Human resources to build innovation-oriented country power gives our country's higher vocational education theory new connotation of the Times, in view of the present vocational colleges graduates cannot satisfy the economic globalization and knowledge economy and social development of innovative skills requirements of the contradiction, urgently need to speed up the pace of higher vocational education personnel training mode innovation and reconstruction of the original curriculum system structure, scientific and reasonable allocation of teaching resources, take the initiative to adapt to the economy, science and technology, social development and the need to build an innovation-oriented country, cultivating high-quality skilled talents with creating innovative spirit. Communication is the foundation of the countries' people economy industry, the application of communication technology and popularization, has entered including fax, video, meeting TV, visual telephone, E-mail address and a new stage of technologies such as electronic data interchange which makes the modern information society for communication network access, exchange, transfer and related application talented person demand surge. At present, such as thumb to improve students' professional practice ability, cultivate high-quality skilled personnel to satisfy the needs of the development of information industry of our country is the problem to be solved. Practice teaching is an important part of training mode of higher education at the present stage, the practice teaching as an important part of the teaching process, is to cultivate students' innovation and ability, is the important means and ways to realize the talent, has a theoretical teaching irreplaceable special role, therefore, must change the "light weight theory practice, knowledge and skills, which will weighs the general verification experiment comprehensive, designing experiments", such as concept, improve the recognition of the importance of practice teaching, deepening the reform of practice teaching, 
strengthen the construction of practice teaching and management further cut the teaching management, construct the practice teaching resources guarantee system, establish and perfect a set of operation mechanism of teaching with practical teaching unitary self [1, 2].

One belt and one road strategy on the concrete implementation includes "please come in" and "going out" two parts. The former is mainly in terms of energy, resources, to the general introduction of other countries and regions resources and raw materials. The latter is our manufactured products exported to all over the world, this also is to industrialized countries from raw material market in China and then to high-tech national transition path. The implementation of this strategy not only wants to rely on hard power, but also rely on soft power. Go out and discuss cooperation, first of all to find mutual excitement, seeking consensus. The second is to use the right way, the right people [3].

Especially the foreign-oriented talents shortage, less talent international exchanges, visiting scholars and study exchange has not yet formed the scale, with international vision, understanding of domestic and international market economy operation law, familiar with international rules and practices to participate in international competition, the serious lack of high quality foreign-oriented talents. Economy construction, therefore, the first thing to supplement the western region of the talents, strengthening the construction of the famous foreign-oriented talents with international vision, not only the talent flow between regions should strengthen international talent exchange will become normal [4]. Human capital is a factor influencing the long-term trend of the regional economic growth. Stock of human capital concept is not only an indicator, and the one who has a structure change of quality index, distribution structure and hierarchy. In economic growth, the role of human capital is different, different levels have different contribution rate of human capital how to optimize configuration, at all levels will affect the human resource's contribution to the development.

In this paper, we conduct theoretical analysis and in-depth discussion on novel information and communication technology talent training mode under the guidance of one belt and one road methodology. All the way along the strategy from the global analyse is the deepening of reform and opening up, strengthen the foreign exchange, a major measure for safeguarding state security and will provide a lasting economic growth and structure adjustment of our country. In the following sub-sections, we will discuss the corresponding issues in detail with analysis.

\section{The Proposed Methodology}

The Communications Professional Teaching. The communication engineering as an important professional of science and engineering colleges and universities, aimed at developing a communications technology, the knowledge of the communication system and communication network. which can be in the field of communication in the sectors of the national economy, national defense industry and work in the design, development, manufacturing operations and other senior professionals. In order to achieve the training goal, the communication engineering and professional curriculum system, practice teaching, reform teaching methods such as the main teaching link, build timely, fundamental and characteristics of professional education is an important task of teaching reform. The problems existing in the teaching of communication could be summarized as the follows: Firstly, the structure and content of the traditional teaching is not an independent mode to adapt to the communications industry related units of the actual need of choose and employ persons. Teaching evaluation mechanism more constrained by evaluation standard of colleges and universities, teachers focus on the more complete workload, nurse the communications professional operability and applicability, which led to the theory of strong and the practical ability is poor. After years of theoretical study, students cannot adapt to the professional engineering after entering the work unit. Practical instructions are presented in the detailed requirements, steps and principles of learning according to the experiment instruction will be prepared according to the steps to use instruments and equipment, the whole process of middle school students can play space is small, and the problems existing in the process also restricted the communication professional personnel training, waste students' time and energy to learning, virtually increased the students' employment difficulty. 
Secondly, set of teaching content and curriculum system structure existence question [5]. The general formation of a curriculum system, not a simple combination of various related courses, but a higher level of mutual fusion. At present, the unreasonable structure of communication engineering specialty course system exists, course teaching content repeated or omission phenomenon. In addition, the communication engineering is the emerging field that is involved in the course series of some belong to the open course, course itself system also needs to be further improved. Determine the curriculum structure and teaching content which can be a reference of things is little, made on the contents of the curriculum structure and teaching has many places need to improve. Thirdly, single teaching methods, insufficient resources; Most teachers one-way infusion, to impart knowledge as the main purpose, take force-feeding teaching method and traditional teaching means, such as slide, wall charts, the blackboard teaching. Though to varying degrees all courses used the multimedia teaching, but still cannot meet the needs of the curriculum system.

At present, the electronic communications professional teaching reform in higher vocational colleges, teachers and students in higher vocational colleges is still faced with many problems. In order to explore the effective ways to electronic communications professional teaching reform in higher vocational colleges, teaching must be combined with the actual life and combined with the feature of each student's personality, to blaze new trails, electronic communications professional teaching to improve students' comprehensive quality. Electronic communications professional teaching in higher vocational colleges should not only teach students electronic communication in professional knowledge, also should pay attention to cultivate the students' subjective initiative, the introduction of a variety of teaching methods, promote the students' comprehensive ability of the general ascension. Electronic communications professional teaching reform in higher vocational colleges, the teachers should be the electronic communications professional teaching content and students practical situation integrate reasonably, build conforms to logic electronic communications professional student life teaching situation, guides the student to form the cognitive sparks, bring up the question of flexible, so that the students actively involved in the study, improve autonomous learning ability.

The One Belt and One Road Methodology. Internal reform and opening to the outside world in China are faced with new breakthrough, on the one hand, the global financial crisis, the European and American market demand decreases, the traditional constrained export-oriented growth model, on the other hand, as China's economy continued rapid growth, structural contradiction is highlighted, in order to adapt to the new normal under the steady growth of economy in our country we propose the theory. The essence of the essence of strategy is a common, cooperation, win-win platform. China and Asian countries, with their neighborhood, rich neighbors, good-neighborly policy, and hope to build a platform on the basis of the economic interests of mutual interests, continuously consolidate the achievements of deepening reform in China, to world peace and development to make their due contribution. "Area" strategy is also the Chinese comprehensive security concept and the embodiment of an independent foreign policy of peace. On the contrary, unlike the Marshall plan during the cold war, after the second world wars and in order to help the European economic recovery, also in order to control the European Allies, and at the same time, in order to fight against the Soviet union and then America's secretary of state George Marshall proposed to the European Allies economic recovery plan, referred to as the "Marshall plan". Although it eventually made the important contributions to the U.S. economic recovery, but also in mainland Europe makes up the iron curtain of the cold war between the east and the west and China's strategy of "area" is committed to the development of the building in the Asia-pacific region innovation, interest integration and linkage open pattern of economic growth, conform to the development requirement of our times and countries to speed up the development of desire, can rapidly along with the country, at the same time, along the national on dividend "high-speed train" to share China's economic development in China, achieve mutual economic development. In addition do not add any political conditions, have the essential differences between it and Marshall plan. More does not result in China in the related area to form a so-called "military alliance". "All the way around China's" strategic initiative does not seek regional affairs 
dominance and sphere of influence, and is not interfering in the internal affairs of region, not only open in the region and country, is also open on the fields of cooperation with the project. "Area" initiative to encourage voluntary participation, follow market law and commercial law, equality and mutual benefit, the parties jointly promote. It is not a Chinese "solo", but the participation of all parties, "symphony. In the Fig. 1, we illustrate the parts and distribution of the policy.

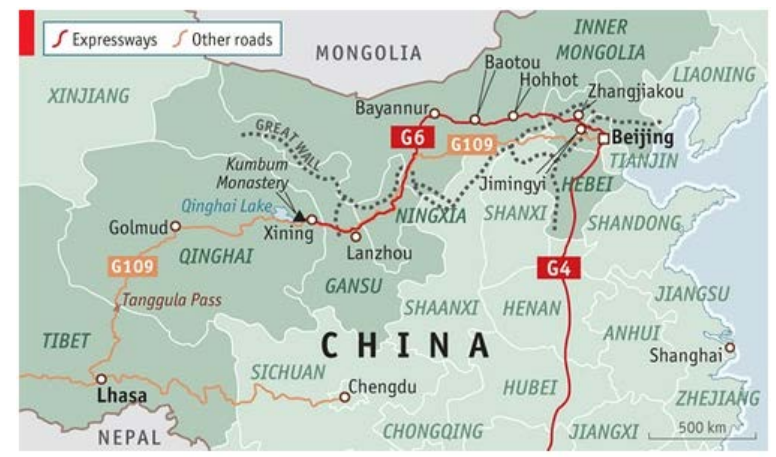

Fig. 1 The Parts and Distribution of the Policy

One belt and one road along the national difference of factor endowments, but we have a common wish, namely the development of economy, countries generally established suitable for the situation of their own development plan, pushing forward the construction of the "area" can be "neighborhood" all the way along the construction plan and the development of the national planning which will make countries give full play to their comparative advantage, realize the complementary advantages [6]. Our country along with most countries established bilateral cooperation mechanisms, such as in agriculture, prime minister proposed by China's high-speed rail construction and Thailand rice in exchange offer and is conducive to maintaining our country's food security, have contributed to the infrastructure construction in Thailand. In energy, strengthen our cooperation with Asia, both can satisfy the energy demand of our country, at the same time, China's manufactured goods for the Asia, manufacturing materials and light industry products, can meet the needs of its industrial development. China and the economic cooperation of countries along the "area" involved in energy, transportation, agriculture, finance, and other fields, tourism, infrastructure, to promote China and along the countries to achieve mutual benefit and common development. China's initiative "area" strategy, can drive along the south-south cooperation in the rapid developing countries and emerging economies, and the second connectivity in the developed countries of the world, through the development of closer economic and trade relations, in the interests of the community is formed on the basis of equality, mutual benefit and common destiny, counter for hegemony a sharp decline in the United States are not to the implementation of the strategy of "Asia Pacific rebalancing", for the world economy's recovery since trudging into new move.

The Novel Information and Communication Technology Talent Training Mode. Practical is a characteristic of specialized courses for communication, therefore, only in the teaching process frequently adhere to the theory with practice, let the students hands-on, brain, can achieve very good teaching effect. In the course under the background of the period of reduction, the amount of information increases, the traditional teaching mode has been a serious challenge, how to do a good job in teaching has become a common concern of teachers. According to own actual situation, to establish the students employment as the guidance, to professional construction as the general starting point, the curriculum reform as the core of the guiding ideology, break traditional is given priority to with theory teaching course system, establish theory teaching, practice teaching and the comprehensive quality form the curriculum system of paying equal attention to three dimensional. How to build the employment as the guidance, to improve the students' professional skills for the purpose of progressive type personnel training mode has become a new way of teaching mode reform [7].

Teacher should also carry out research and scientific research work, only the summary of the research, from the classroom, from teaching, from practice to reflect continuously, improve the 
quality of teaching. In teachers also hired a line of engineering and technical personnel and rich practical experience of professional scholars as part-time teachers to the school, enterprise engineer experience, has the rich project experience, through the enterprise post demand and real project in our school is suitable for consolidating the student training project, led by enterprise engineers work with all items in the characteristic and demand which will accelerate and enhance the professionalization process of students. We should change the traditional ideas, advancing with The Times, continuous innovation, for the professional characteristics of mobile communication technology, optimize the curriculum, deepen teaching reform, strengthening the construction of teaching staff, enhancing university-enterprise cooperation, for the society to create more suitable for social demand high levels of talents.

\section{Summary}

In this paper, we conduct theoretical analysis and in-depth discussion on novel information and communication technology talent training mode under the guidance of one belt and one road methodology. Cooperation between China and the Shanghai cooperation organization member states is solid. Within the framework of the Shanghai cooperation organization, the member countries to strengthen the mutual trust and the essential good-neighborly friendship, promote the member states in political, economic and trade, science and technology, culture, energy, the modern communication network by telephone communication network, mobile communication network, data communication network, computer communication network, and other basic network components. In the communication of professional teaching, it should have and the actual corresponding to pass each other in multiple users ask a variety of information network rotation, tourism and the security effectively. Our country's higher vocational education is to train skilled and applied talents for the connotation of talents cultivation pattern, of a large number of communication for the communication industry. However, higher vocational colleges in the face of the enterprise and society to professional communication talents, qualifications, in terms of the degree of demand remains to be better, improve and improve. Our research provides us with the novel standard which will be meaningful and effective.

\section{Acknowledgements}

This work was financially supported by the 2015 Teaching Reform Research Planning Project of Xijing University (JGGH1511).

\section{References}

[1] H. L. Wang, X. S. Zhang: Exp. Tech. \& Management Vol. 29 (2012), p. 129, in Chinese.

[2] L. Y. Han, Y. H. Feng: Journal of Science of Teachers College \& University No.2 (2014), p. 89, in Chinese.

[3] T. Li, P. J. Qiao and Y. Zhang: Journal of Shandong Institute of Physical Education \& Sports Vol. 29 (2013), p.110, in Chinese.

[4] T. Zhang: Journal of Sichuan University of Science \& Engineering Vol. 28 (2013), p. 97, in Chinese.

[5] Q. Wang, F. E. Wei, L. Feng: Meitan Higher EducationVol. 31 (2013), p. 88, in Chinese.

[6] S. Z. Xie, Z. F. Chen, D. F. Zha: Journal of Nanchang College of Education Vol. 26 (2011), p. 92, in Chinese.

[7] X. H. Li, Y. X. Zhang, Y. F. Wang and Z. S. Li: Experiment Science \& Technology Vol. 12 (2014), p. 139, in Chinese. 